\title{
LATIN AMERICAN SCIENTIFIC PRODUCTION ON MENTAL HEALTH IN TIMES OF COVID-19
} \author{
Fernando Escobedo 3 \\ ${ }^{1}$ Unidad de Virtualización Académica, Universidad de San Martin de Porres, Lima, Perú \\ ${ }^{2}$ Escuela de Psicología, Universidad Nacional de Tumbes, Tumbes, Perú \\ ${ }^{3}$ Universidad Católica los Ángeles de Chimbote, Chimbote, Perú
}

Ronald M. Hernández ${ }^{1}$, Miguel A. Saavedra-López ${ }^{2,3}$, Xiomara M. Calle-Ramirez ${ }^{2}$, Julio Cjuno ${ }^{3}$ and

Corresponding author: Ronald $M$. Hernández

Email: rhernandezv@usmp.pe

\begin{abstract}
The main characteristics of publications on mental health in times of COVID-19, made by authors affiliated with Latin American institutions, are here described. A retrospective and descriptive analysis of 2,656 articles indexed in Scopus database during 2020 is conducted. This database was chosen for its high-quality scientific journals. The results indicate that Latin American scientific production represents $4.74 \%$ of the world production, and Brazil is the country with the largest production of publications, followed by Colombia, Mexico and Chile. Latin American scientific works have been published in 82 journals. Psychiatry Research is the journal with the largest number of publications, followed by Estudos De Psicologia Campinas (Brazil). The authors are mainly affiliated with institutions in Brazil, and Universidade Federal do Rio Grande do Sul as well as Universidad del Rosario in Colombia are the institutions with the largest number of publications. Review articles and letters to the editor are the most cited types of publications. Finally, it was found that the most used keywords were the descriptors coronavirus, pandemic, mental disease, mental health problems such as anxiety and depression. We conclude that in Latin America there is a need for further research on mental health among health care personnel and the general population in order to establish knowledge that creates public policies for mental health problems generated during the course of the pandemic.
\end{abstract}

Keywords: Latin America; Scientific production; mental health; COVID-19; pandemic.

\section{INTRODUCTION}

The COVID-19 virus has become a global health crisis $^{1}$ with a high level of contagiousness, causing infections and deaths to increase significantly. This not only causes the virus to spread, but also negative thoughts and emotions to threaten the population mental health and well-being ${ }^{2,3}$. Therefore, the pandemic involves a challenge in the care of people's physical and mental health, including health personnel, since they are the frontline team and are exposed to specific work demands and requirements with high levels of stressors affecting their mental health ${ }^{4,5}$.

Likewise, those people who are in social isolation with restricted mobility and scarce contact with other people are more likely to develop psychiatric complications. They may present from isolated symptoms to disorders affecting the quality of sleep that contribute to the appearance of anxiety, post-traumatic stress disorders and depression ${ }^{6}$, which can lead to a reduction in people's active lifestyles ${ }^{7}$.

Even though there is no percentage of mental health problems worldwide in the COVID-19 health crisis so far, some psychosocial situations have caused a considerable degree of fear and concern in the general population, old people, health personnel and people with chronic diseases that, to date, has generated high rates of stress or anxiety. Levels of loneliness, depression, harmful alcohol and drug use, selfharm or suicidal behavior ${ }^{8}$ are also expected to increase.

After the pandemic, mental health problems will remain and will require significant attention and investment from authorities and governments 9 This is alarming, because before the health crisis, there were several barriers for people with mental health problems to have appropriate access to health services, such as long distances to health facilities, lack of awareness of their mental health problems, and distrust of health personnel or the stigma attached to the care of these problems ${ }^{10}$.

During and after the COVID-19 health crisis, the mental health will be more precarious and will require improvements through studies, mainly in developing countries such as those in the Latin American region ${ }^{11}$. This situation shows the growing need to value the knowledge ${ }^{12}$ production and dissemination processes, acquiring relevance in the structuring of 
scientific research and management policies in health areas ${ }^{13}$.

In this respect, it is extremely important to have a view from bibliometrics, about the scientific advance regarding mental health care, evaluation and promotion in times of COVID-19. In light of the foregoing, the objective of this study was to describe the Latin American scientific production on mental health in times of COVID-19.

\section{METHODS}

A retrospective descriptive study considered, as an analysis unit, the publications on mental health in journals indexed in Scopus during the period 2020 and whose authors are affiliated with Latin American institutions. Scopus includes more than 40,804 journals of science, technology, social sciences, arts, humanities and medicine ${ }^{14}$. It was decided to use this database due to the huge number of biomedical journals included there and to its rigorous journals' selection process, which allows to collect the most relevant studies on the subject. The search was made on August 22, 2020 and included all articles published and indexed from January to August, 2020, using the fields Article Title,
Abstracts, Keywords, putting in the search terms the words: (Mental health OR mental disorders OR mental health care OR mental disturbances OR mental illness OR substance-related disorders OR addictions OR behavior, addictive OR drug abuse $O R$ substance abuse $O R$ violence $O R$ burnout syndrome $O R$ stress $O R$ post-traumatic OR depression OR depressive disorder OR suicide OR bullying), and their relation with the terms (2019-nCoV OR SARS-CoV-2 OR2019 novel coronavirus" OR COVID-19 OR "Coronavirus disease 2019). With the extracted documents, a database was organized in Microsoft Excel that included the following data: name of the signatory authors, publication title, type of publication, affiliation institutions of the signatory authors, publication journal and country of edition. Finally, a network with the main themes associated with the publications' keywords was created with the support of the VOSviewer software.

\section{RESULTS}

We found a total of 2,656 articles published and indexed in Scopus worldwide, of which $4.74 \%$ $(n=126)$ represent authors affiliated with Latin American institutions. Six types of publications were included in the analysis (table 1).

Table 1: Types of Publications on Mental Health and COVID-19

\section{Type of Publication}

Articles

Letter to the Editor

Reviews

Editorial

Notes

Brazil is the Latin American country that contributes with the greatest scientific production on mental health, representing $2.86 \%$ of the world production, followed by Colombia, Mexico, and Chile, countries that have 10 or more publications. There are five countries in Latin America (Panama, Dominican Republic, Guatemala, Honduras and Jamaica) that have at least one publication on the studied variables (Table 2).

Latin American scientific production has been published in 82 journals. Psychiatry Research is the journal with the largest number of publications on mental health and COVID-19 (n $=11$ ). Table 3 shows the first 10 journals with the highest production. We can observe that Latin American authors do not only publish in local journals; foreign journals also appear such as the International Journal of Environmental Research and Public Health and Asian Journal of Psychiatry, and others that publish research works by Latin American authors. From this ranking, two have an index $h>100$. Three of the ten journals are in quartile 1 of Scopus. It is important to highlight those four out of the ten most productive journals are published in Brazil. In addition, according to Scopus, most journals are classified in the areas of Psychiatry and Mental Health; Psychology; Medicine; Neurology and Behavioral Neuroscience. 
Table 2: Percentage Distribution of the Scientific Production on Mental Health and COVID-19 by Latin American Countries

\begin{tabular}{lcc}
\hline Country & $\mathbf{n}$ & \% of Contribution by Country \\
\hline Brazil & 76 & 2.86 \\
Colombia & 18 & 0.68 \\
Mexico & 15 & 0.56 \\
Chile & 11 & 0.41 \\
Argentina & 8 & 0.30 \\
Peru & 7 & 0.26 \\
Ecuador & 6 & 0.23 \\
Cuba & 4 & 0.15 \\
Paraguay & 4 & 0.15 \\
Puerto Rico & 2 & 0.04 \\
Uruguay & 2 & 0.08 \\
Panama & 1 & 0.08 \\
Dominican & 1 & 0.04 \\
Republic & & 0.04 \\
Guatemala & 1 & 0.04 \\
Honduras & 1 & 0.04 \\
Jamaica & 1 & \\
\hline
\end{tabular}

Table 3: Journals with Articles Published on Mental Health and COVID-19

\begin{tabular}{|c|c|c|c|c|c|}
\hline Journal & $\mathrm{n}$ & Country & H Index & Quartile & Category \\
\hline Psychiatry Research & 11 & Ireland & 127 & Q1 & $\begin{array}{l}\text { Psychiatry and } \\
\text { Mental Health }\end{array}$ \\
\hline Estudos De Psicologia Campinas & 6 & Brazil & 6 & Q3 & Psychology \\
\hline Asian Journal Of Psychiatry & 4 & $\begin{array}{l}\text { The } \\
\text { Netherlands }\end{array}$ & 29 & Q2 & $\begin{array}{l}\text { Psychiatry and } \\
\text { Mental Health }\end{array}$ \\
\hline $\begin{array}{l}\text { International Journal Of } \\
\text { Environmental Research And Public } \\
\text { Health }\end{array}$ & 4 & Switzerland & 92 & Q2 & $\begin{array}{l}\text { Public Health, } \\
\text { Environmental } \\
\text { and } \\
\text { Occupational } \\
\text { Health }\end{array}$ \\
\hline Brain Behavior And Immunity & 3 & $\begin{array}{l}\text { United } \\
\text { States }\end{array}$ & 140 & Q1 & $\begin{array}{l}\text { Behavioral } \\
\text { Neuroscience }\end{array}$ \\
\hline Brazilian Journal Of Psychiatry & 3 & Brazil & 50 & Q2 & $\begin{array}{l}\text { Psychiatry and } \\
\text { Mental Health }\end{array}$ \\
\hline Cadernos De Saúde Pública & 3 & Brazil & 72 & Q2 & Medicine \\
\hline Ciência E Saúde Coletiva & 3 & Brazil & 41 & Q2 & Medicine \\
\hline Interamerican Journal Of Psychology & 3 & Puerto Rico & 18 & Q3 & Psychology \\
\hline Lancet Psychiatry & 3 & $\begin{array}{l}\text { United } \\
\text { Kingdom }\end{array}$ & 65 & Q1 & $\begin{array}{l}\text { Psychiatry and } \\
\text { Mental Health }\end{array}$ \\
\hline
\end{tabular}

Table 4 presents the first ten institutions with the largest number of articles, mostly published in Brazil. Universidade Federal do Rio Grande do $\mathrm{Sul}$ is the institution with the largest number of articles $(n=8)$. Institutions from other countries such as Universidad del Rosario (Colombia) appear in this list. 
Table 4: Latin American Institutions with Articles Published on Mental Health and COVID-19

\begin{tabular}{llc}
\hline Institution & $\mathbf{n}$ & Country \\
\hline Universidade Federal do Rio Grande do Sul & 8 & Brazil \\
Universidade do Porto & 6 & Brazil \\
Universidade de São Paulo - USP & 6 & Brazil \\
Fundação Universitária do ABC, School of Medicine of ABC & 6 & Brazil \\
School of Medicine of Juazeiro do Norte & 5 & Brazil \\
Fundação Oswaldo Cruz & 5 & Brazil \\
Pontifícia Universidade Católica de Campinas & 5 & Brazil \\
Universidad del Rosario & 5 & Colombia \\
School of Medicine Estácio of Juazeiro do Norte Estácio/FMJ & 4 & Brazil \\
Universidade Federal de São Paulo & 4 & Brazil \\
Universidade Federal do Cariri & 4 & Brazil \\
Universidade Federal do Rio de Janeiro & 4 & Brazil \\
\hline
\end{tabular}

The total number of citations for all publications was 395 , with an average of 3.13 citations. Table 5 shows the five most cited publications on mental health and COVID-19, and the review articles and letters to the editor are the most cited types of publication.

Table 5: Most Cited Articles on Mental Health and COVID-19

\begin{tabular}{|c|c|c|c|c|}
\hline Authors & Title & Journal & Citations & Type of Document \\
\hline $\begin{array}{l}\text { Torales, } \\
\text { J. et al. }\end{array}$ & $\begin{array}{l}\text { The outbreak of COVID-19 coronavirus } \\
\text { and its impact on global mental health }\end{array}$ & $\begin{array}{l}\text { International } \\
\text { Journal of Social } \\
\text { Psychiatry }\end{array}$ & 76 & Review \\
\hline $\begin{array}{l}\text { Tavares, } \\
\text { C. et al. }\end{array}$ & $\begin{array}{l}\text { The emotional impact of Coronavirus } \\
2019-n C o V \text { (new Coronavirus disease) }\end{array}$ & $\begin{array}{l}\text { Psychiatry } \\
\text { Research }\end{array}$ & 67 & Letter \\
\hline $\begin{array}{l}\text { Ornell, F. } \\
\text { et al. }\end{array}$ & $\begin{array}{l}\text { "Pandemic fear" and COVID-19: } \\
\text { Mental health burden and strategies }\end{array}$ & $\begin{array}{l}\text { Brazilian Journal } \\
\text { of Psychiatry }\end{array}$ & 36 & Editorial \\
\hline $\begin{array}{l}\text { Moreira, } \\
\text { P. et al. }\end{array}$ & $\begin{array}{l}\text { The psychiatric impact of the novel } \\
\text { coronavirus outbreak }\end{array}$ & $\begin{array}{l}\text { Psychiatry } \\
\text { Research }\end{array}$ & 22 & Letter \\
\hline $\begin{array}{l}\text { Lloyd- } \\
\text { Sherlock, } \\
\text { P.G., et } \\
\text { al. }\end{array}$ & $\begin{array}{l}\text { WHO must prioritize the needs of older } \\
\text { people in its response to the covid-19 } \\
\text { pandemic }\end{array}$ & The BMJ & 15 & Letter \\
\hline
\end{tabular}

Based on the registry, Figure 1 shows the main keywords associated with research on mental health and COVID-19. Only 61 (table 6 ) out of the 1,105 keywords met this threshold. We can see three clusters that group the various relationships of the concepts and in which cocitation networks related to each other, according to the strength of association obtained by the VOSviewer program, can be visualized. Moreover, it can be observed that the most common descriptor is "Pandemics", followed by "Coronavirus disease" and "mental disease". In this case, the number of co-occurrence of two words indicates the number of publications in which both words appear in the list of keywords of the selected documents. Cluster 1 (blue) includes the description of coronavirus infection and psychological aspects in the health of health care personnel. Cluster 2 (red) describes mental diseases and risk factors in personnel and health care access. Cluster 3 (green) stresses aspects related to quarantine for COVID-19 infection and its connection with anxiety and depression. 


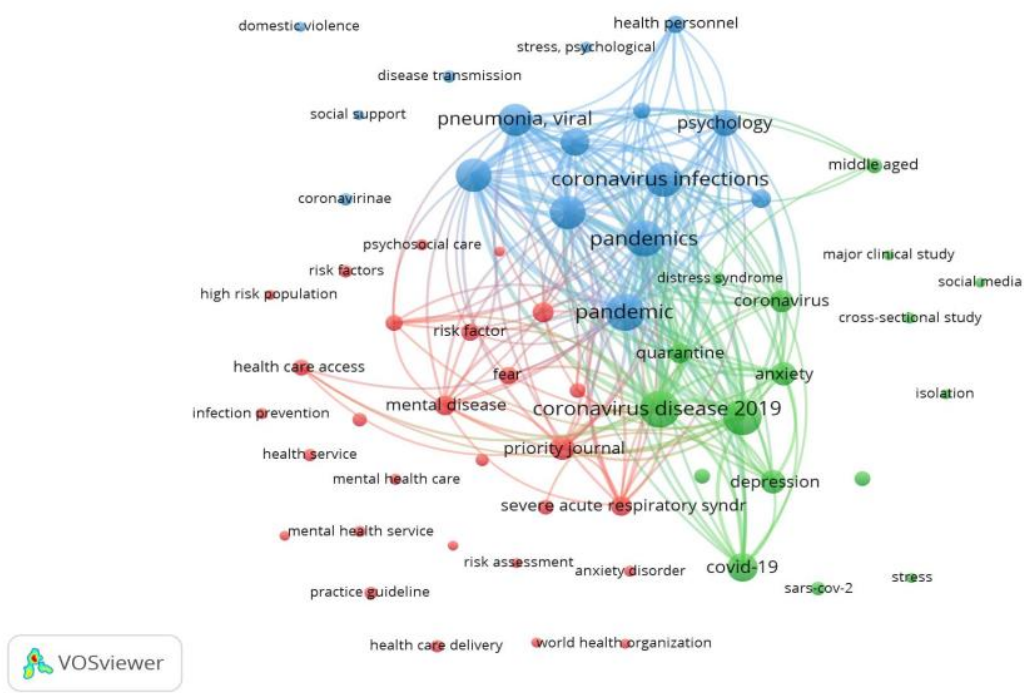

Figure 1. Visualization of a keyword occurrence network on mental health in times of COVID-19.

Table 6: Thematic approach within each cluster of keywords

\begin{tabular}{|c|c|c|c|}
\hline Cluster & Keyword & Occurrences & Thematic approach \\
\hline \multirow[t]{5}{*}{ Cluster 1 (blue) } & Pandemics & 45 & \multirow{5}{*}{$\begin{array}{l}\text { Pandemic for } \\
\text { coronavirus infection } \\
\text { and psychological } \\
\text { aspects in the health of } \\
\text { health care personnel }\end{array}$} \\
\hline & Coronavirus infections & 40 & \\
\hline & Pneumonia viral & 39 & \\
\hline & Psychology & 25 & \\
\hline & Health personnel & 16 & \\
\hline \multirow[t]{5}{*}{ Cluster 2 (red) } & Mental disease & 27 & \multirow{5}{*}{$\begin{array}{l}\text { Mental diseases and risk } \\
\text { factors in personnel and } \\
\text { health care access }\end{array}$} \\
\hline & Risk factor & 25 & \\
\hline & Coronavirus & 24 & \\
\hline & Respiratory syndrome & 20 & \\
\hline & Health care access & 16 & \\
\hline \multirow[t]{5}{*}{ Cluster 3 (green) } & Coronavirus disease 19 & 50 & \multirow{5}{*}{$\begin{array}{l}\text { Quarantine and its } \\
\text { connection with anxiety } \\
\text { and depression }\end{array}$} \\
\hline & Quarantine & 45 & \\
\hline & Anxiety & 32 & \\
\hline & Depression & 30 & \\
\hline & Distress syndrome & 24 & \\
\hline
\end{tabular}

\section{DISCUSSION}

Performing an analysis of the scientific production in Latin America on mental health and COVID-19 reflects the concern to highlight this issue, which has not yet drawn the attention of authorities worldwide since the WHO (2019) in its strategic plan for COVID-19 has not specified strategies of any kind to address mental health needs ${ }^{15}$. This shortcoming would be a mistake, since the integration of mental health into public health preparedness and health emergency response strategies will effectively curb endemic outbreaks ${ }^{16}$.
Of the publications made in Latin America, Brazil is the country that has produced the largest number of studies on mental health in Latin America, followed by Colombia, Mexico and Chile. Luna-Solís (2015) states that, in South America, the countries with the highest scientific production on mental health indexed in Scopus are Brazil, Chile, Argentina and Colombia ${ }^{17}$. Similar results were found in a study where they reviewed the SCiELO database, finding that Brazil stands out as the main country in scientific production on health, followed by Cuba, Colombia, Chile and Argentina ${ }^{18}$. The research conducted worldwide related to mental health and COVID-19 in the PudMed database identifies 
Brazil as one of the seven countries that have considered mental health as a topic of research associated with the current pandemic ${ }^{19}$. Additionally, research scientific results may significantly increase in the medium term due to the number of countries committed to researching on COVID-19 and its impact on mental health.

Research on the journals that have produced the largest number of articles on mental health and COVID-19 was conducted; and it was found that the scientific productions are in quartiles 1 and 2 of SRJ, demonstrating the high visibility of research carried out by Latin American researchers. There is a tendency to publish in peripheral journals, mostly in Europe and the United States. These results show that these journals offer an opportunity of publication to Latin American researchers in view of the current situation where knowledge and causes both physical and especially psychological- of COVID-19 are essential to investigate ${ }^{20}$. Publication in scientific journals with good indicators (citations, impacts, quartiles) involves a huge number of citations and visibility for Latin American authors.

Among the institutions with the highest production are Brazilian universities such as Universidade Federal do Rio Grande do Sul, Universidade do Porto and Universidade de São Paulo - USP, and Colombian universities such as Universidad del Rosario. Likewise, a study on Latin American scientific production during COVID-19 was conducted, also finding that Brazil and Colombia have the highest production per institution ${ }^{21}$. These results show the significance of international collaboration, a vision that journals of Latin American countries may adopt to basically form institutional networks. Furthermore, leadership and publication in international journals reflect coordinated efforts in the search of disease responses.

We found that review articles and letters to the editor are the most cited publications. SanzValero, Tomás Casterá and Wanden-Berghe (2014) conducted a bibliometric study on scientific production published by the Pan American Journal of Public Health, finding that the most cited types of documents were scientific articles with $69.69 \%$, followed by online monographs ${ }^{22}$.

Finally, the analysis of co-occurrence of words that were mostly used by authors is visualized. This analysis resulted in three groups and reflects the different approaches on published studies, which clarifies the research trends on the topic under study. Words such as COVID-19, and its different adopted names, as well as the risk factors and treatments necessary for mental health, are related to the results of other global research works ${ }^{23}$. The most significant aspect of this result is that mental health research in Latin
America is developed in line with the research conducted in European countries ${ }^{24}$. Likewise, the existence of common psychological reactions to the pandemic such as depression and anxiety between $16 \%$ and $28 \%$ and self-reported stress in $8 \%{ }^{19}$ is demonstrated. Thus, depression, reaction to stress and anxiety have been identified as the initial mental health problems since the onset of the pandemic; findings that reveal the importance of developing mental health intervention strategies ${ }^{2}$.

\section{CONCLUSIONS}

The Latin American scientific production on mental health is still limited. It emphasizes the lack of studies that assess and list public health interventions. Brazil is the country with the largest scientific production and studies on which collaboration networks are focused. These results demand to continue encouraging mental health research, with emphasis on public health interventions, and on the support and empowerment of institutions and collaboration networks located outside Latin America.

There is a growing need to continue researching mental health, of both health personnel and the general population, in order to establish knowledge that contributes to public policies for the reduction of psychological and psychiatric problems such as anxiety, post-traumatic stress and depression, which will keep appearing throughout the course of the pandemic and will increase significantly.

This study shows the importance of networking to carry out research works to be published in high-impact journals, since developing networks contributes to overcoming various institutional limitations.

Based on the network analysis, we recommend that networking or collaboration networks must grow in order to increase scientific production. Some additional recommendations that may help with the growth of scientific production of a studied variable are affiliating with high production national institutions to have access to their international networks, and training human resources personnel in research contents, among others.

It should be taken into account that the study only evaluates publications in journals indexed in Scopus, since it sought to evaluate the scientific production in quality journals. However, other studies may have been published in journals that are not indexed in said database.

The identification of scientific production on mental health is an important achievement, since it increases visibility worldwide, all the more so when it is possible to further deepen this vision with data that can be found in other databases such as Web of Science, PubMed, among others. The development of a set of 
predesigned search strategies is also important, since it will allow a rapid exploration of databases in short trial periods, facilitating the compilation of scientific production of a variable.

\section{Conflict of interest}

The authors declare no potential conflict of interest.

\section{REFERENCES}

1. Gallegos $M$, Cervigni $M$, Consoli AJ, et al. COVID-19 in Latin America: A Bibliometric Analysis of Scientific Publications in Health. Electron $J$ Gen Med 2020; $17 \quad$ (6): em261. https: //doi.org/10.29333/ejgm/ 8460 (Visited October 20, 2020).

2. Huarcaya-Victoria J. Consideraciones sobre la salud mental en la pandemia de COVID-19. Rev Peru Med Exp Salud Publica 2020; 37(2):327-34. https://doi. org/10.17843/rpmesp.2020.372.5419 (Visited September 19, 2020).

3. Martínez L, Valencia I, Trofimoff V. Subjective wellbeing and mental health during the COVID-19 pandemic: Data from three population groups in Colombia. Data in Brief 2020; 32:1-14. Doi: 10.1016 / j.dib.2020.106287 (Visited September 18, 2020).

4. Fernandes M, Ribeiro A. Salud mental y estrés ocupacional en trabajadores de la salud a la primera línea de la pandemia de COVID-19. Revista Cuidarte 2020; 11(2): e1222. http://dx.doi.org/10.15649/cuidarte.122 2 (Visited October 5, 2020).

5. García-Iglesias JJ, Gómez-Salgado J, Martín-Pereira J, et al. Impacto del SARS-CoV-2 (COVID-19) en la salud mental de los profesionales sanitarios: una revisión sistemática. Revista Española de Salud Pública 2020 jul 23; e202007088. (Visited on October 29, 2020).

6. Huremovic D. Psychiatry of pandemics: a mental health response to infection outbreak. Springer: English. 2019.

7. Camacho-Cardenosa A, CamachoCardenosa M, Merellano-Navarro E, et al. Influencia de la actividad física durante el brote en los estados psicológicos en adultos en la pandemia COVID-19: un protocolo de estudio. Revista Española de Salud Pública 2020; 94(1): e1-e9 e202006063 (Visited October 10, 2020).
8. Organización Panamericana de la Salud OPS. Consideraciones psicosociales y de salud mental durante el brote de COVID19. 2020. https://smaps-coronavirus-esfinal-17-mar-20.pdf (Visited September 18, 2020).

9. Li W, Yang Y, Liu ZH, et al. Progression of Mental Health Services during the COVID-19 Outbreak in China. International journal of biological sciences 2020; 16(10), 1732-1738. DOI: https: / /doi.org/10.7150/ijbs. 45120 (Visited October 6, 2020).

10. Andrade LH, Alonso J, Mneimneh Z, et al. Barriers to mental health treatment: results from the WHO World Mental Health surveys. Psychological medicine 2014; 44(6), 1303-1317. https: / / doi.org/10.1017/S003329171300 1943 (Visited September 25, 2020).

11. Pfefferbaum B, North C. Mental Health and the COVID-19 Pandemic. Perspective 2020; 383:510-512. DOI: 10.1056/NEJMp2008017 (Visited October 18, 2020).

12. Solano E, Castellanos SJ, López MM, et al. Bibliometría: una herramienta eficaz para evaluar la actividad científica postgraduada. Revista Electrónica de las Ciencias Médicas en Cienfuegos 2009; 7(4), 59-62. http://scielo.sld.cu/pdf/ms/v7n4/v7n4a 745.pdf (Visited December 27, 2020).

13. Juárez-Rolando P. Bibliometría para la evaluación de la actividad científica en ciencias de la salud. Rev Enferm Herediana 2016; 9(1), 57-61. https: / / faenf.cayetano.edu.pe/images/2 016/pd2016/bibliometria.pdf (Visited December 18, 2020).

14. Elsevier. Scopus - Content 2020. https://www.elsevier.com/solutions/sco pus/content. (Visited December 18, 2020).

15. Organización Mundial de la Salud. Nuevo coronavirus 2019 -nCoV: plan estratégico de preparación y respuesta. 2020. https: / /www. who.int/docs/defaultsource/coronaviruse/srp-04022020.pdf (Visited September 20, 2020).

16. Dong L, Bouey J. Crisis de salud mental pública durante la pandemia de COVID19, China. Enfermedades infecciosas emergentes 2020; 26(7), 1616-1618. https: / /dx.doi.org/10.3201/eid2607.200 407. (Visited October 14, 2020).

17. Luna-Solís Y. Producción científica en salud mental en Perú. Reto en tiempos 
de reforma de salud. Acta Med Per 2015; 32(1):36-40. (Visited October 17, 2020).

18. Carvajal-Tapia A, Carvajal-Rodríguez E. Producción científica en ciencias de la salud en los países de América Latina, 2006-2015: análisis a partir de Scielo. Revista Interamericana de Bibliotecología 2018; 42(1). DOI: 10.17533/udea.rib.v42n1a02. (Visited September 6, 2020).

19. Ravi PR. COVID-19 and mental health: A review of the existing literature. Asian Journal of Psychiatry 2020; 52(2020) 1020662.

Doi:

https://doi.org/10.1016/j.ajp.2020.1020 66 (Visited October 20, 2020).

20. Zambrano D, Serrato-Alvarez D, GalindoCaballero OJ. Psicología desde el Caribe; Barranquilla 2021; 38(1). Recuperado de:

https: / /search.proquest.com/openview/ deb3c57582746531c1fa43affbac7eaa/1?p q-origsite $=$ gscholar\&cbl=2027439 (Visited September 19, 2020).

21. Gregorio-Chaviano O, Limaymanta C, López-Mesa E. Análisis bibliométrico de la producción científica latinoamericana sobre COVID-19. Biomédica 2020; 40: 0000. DOI: $10.7705 /$ biomedica. 5571 (Visited September 7, 2020).

22. Sanz-Valero J, Tomás Casterá V, Wanden-Berghe C. Estudio bibliométrico de la producción científica publicada por la Revista Panamericana de Salud Pública en el período de 1997 a 2012. Rev Panam Salud Publica 2014; 35(2):81-8. (Visited October 19, 2020).

23. Kokol $P$, Blažun $H$, Završnik, J. Application of bibliometrics in medicine: A historical bibliometrics analysis. Health Info Libr $J 2020$. https://doi.org/10.1111/hir.1229524. (Visited December 17, 2020).

24. Zhang $L$, Li B, Jia $P$, et al. An analysis of global research on SARS-CoV-2. Sheng $W u$ Yi Xue Gong Cheng Xue Za Zhi 2020; 37:236-45. https: / / doi.org/10.7507/1001 5515.202002034 (Visited December 15, 2020). 